\title{
What Really Affects German Firms' Effective Tax Rate?
}

\author{
Anastasia Kraft $^{1}$ \\ ${ }^{1}$ Accounting \& Corporate Governance, Carl von Ossietzky University Oldenburg, Oldenburg, Germany \\ Correspondence: Anastasia Kraft, Accounting \& Corporate Governance, Carl von Ossietzky University Oldenburg, \\ Ammerländer Heerstr. 114-118, Oldenburg 26129, Germany. Tel: 49-151-5800-3497. E-mail: \\ anastasia.kraft@uni-oldenburg.de
}

Received: March 2, 2014

Accepted: March 22, $2014 \quad$ Online Published: May 29, 2014

doi:10.5430/ijfr.v5n3p1

URL: http://dx.doi.org/10.5430/ijfr.v5n3p1

\begin{abstract}
This paper investigates the determinants of the effective tax rate (ETR) of German firms spanning the Germany's Corporate Tax Reform 2008 (GTR08). This paper is the first to analyze the drivers of ETR using German longitudinal data. The results show that larger companies, growth firms, and firms with higher free cash flow (FCF) appear to have higher ETR. Leverage and operating lease expenses tend to be negatively associated with ETR. The findings show that more profitable firms appear to engage more in tax strategies that result in lower ETRs. Moreover, they indicate that multinational firms have more possibilities to reduce the tax burden, resulting in a negative association with ETR. Germany's tax reform of 2008 has a negative effect on ETR and impacts some firm-specific factors. For more levered firms, the association between leverage and ETR is positive affected by the ETR.
\end{abstract}

Keywords: effective tax rate, tax reform, tax avoidance, multinational, capital structure, growth firms, mature firms

\section{Introduction}

Due to globalization, tax authorities are concerned about the impact of taxes on global trade and investments, differences and interactions of domestic tax systems, which can result in aggressive tax activities of multinational firms and lead to firm's competitive disadvantages which operate only in domestic market. OECD (2013) discusses concerns of these issues in the Report on Base Erosion and Profit Shifting (BEPS) and the Action Plan on BEPS. Including these concerns, Germany's legislation passes the Corporate Tax Reform of 2008 (GTR08). GTR08 seeks to reduce corporate and trade tax rate and to broad the tax base by limiting deductions of interest expenses, rents, and leases and also abolishing the declining depreciation.

This paper analyzes the association between firm characteristics and the effective tax rate (ETR) of German firms using longitudinal data. Accordingly, it enriches the international empirical literature on the determinants of ETR since there is hardly any German empirical evidence on these factors. The paper investigates whether firm size, foreign operations, and capital structure are associated with ETR. Since leasing is a form of financing, the analysis includes operating lease expenses that are not recognized on the balance sheet and are deductible from the tax base. Moreover, the paper examines whether free cash flow, profitability, and growth and mature firms show a different association with ETR. Moreover, this study analyzes the effect of GTR08 on ETR and whether the tax reform impacted the relationship between firm-specific factors and ETR.

While there is a large literature base of descriptive and qualitative studies on the ETR of German listed firms (e.g., Demple, 2006; Mammen, 2011), empirical analyses are rare. Sureth et al. (2009) conduct the only empirical study for German companies using a univariate analysis to analyze the impact of firm characteristics on ETR. However, their study has inconsistent results. This paper enhances the discussion in that it provides the first multivariate analysis of ETR using panel data of German companies and extends the existing literature on ETR-related research.

Previous studies report mixed results for the relationship between ETR and size, leverage, and foreign operations (Siegfried, 1972; Porcano, 1986; Omer et al., 1991; Gupta \& Newberry, 1997; Stickney \& McGee, 1997; Richardson \& Lanis, 2005; Liu \& Cao, 2007; Amstrong et al., 2012). In accordance with prior research, I define ETR as the ratio of income tax to pre-tax income. The analysis shows that larger firms are associated with higher ETR, which is consistent with political cost theory and supports the findings of Zimmerman (1983) and Rego (2003). The results of this paper show that firms with higher leverage and rent/operating lease expenses and multinational operations appear to have lower ETR. The association of firms that began to report foreign sales during the period under review 
(2005 - 2011) is analyzed, revealing a negative relationship between the dummy variable used and ETR. Furthermore, the size of these firms is also negatively related to ETR. Hence, it appears that larger multinational firms have more possibilities to exploit tax differences in order to reduce their tax burden. The findings indicate that firms with higher free cash flow are associated with higher ETR. By contrast, return on assets (ROA) is negatively related to ETR. It therefore seems that more profitable firms engage more frequently in tax avoidance strategies. The present analysis differentiates between growth and mature firms and includes implications of stock valuation. Growth firms appear to have higher ETR. However, the regression results show no significance for mature firms.

Investigating, Germany's tax reform of 2008, I find evidence that GTR08 is negatively associated with ETR, which indicates that the reduction in tax rates overcompensates the limited deductions from the tax base. GTR08 positively impacted ROA and both, mature and growth firms. The negative association between ETR and leverage, ROA, and foreign sales remains after the tax reform. For more levered, I find evidence that GTR08 positively impacted the association between leverage and ETR, which results from limited deductions of interest expenses from the tax base.

This study contributes to the empirical research on ETR in several ways. Using panel data analysis, it adds to the German body of research which still lacks a detailed analysis of factors that influence ETR. To my best knowledge, there is no study that analyzes the impact of GTR08 and effect of firm-specific factors discussed above on ETR after the enactment of German tax reform in 2008. This paper expands the scope of international ETR research as a whole by re-analyzing prominent hypotheses that have thus far produced controversial results by using a model that accounts for autocorrelation and heteroscedasticity. Furthermore the study contributes to the literature that analyzes the effect of tax reforms on ETR (e.g., Newberry, 1997; Richardson \& Lanis, 2007) by investigating the impact of GTR08 on ETR and whether GTR08 had an effect on the association of firm characteristics and ETR. Moreover, it covers other firm-specific factors that appear to influence ETR. This paper is relevant to regulators, researchers who deal with tax issues, and investors who use tax related information for their decisions.

The remainder of this paper is organized as follows. The next section reviews the prior research. Section 3 develops the hypotheses. Section 4 describes the variables and the research design. Section 5 contains the empirical results of the analyses. Section 6 concludes.

\section{Previous Research}

Most research on ETR has been conducted for US firms. In recent years, other international studies followed with analyses of the Australian (e.g., Richardson \& Lanis, 2007), Chinese (e.g., Liu \& Cao, 2007), German (Sureth et al., 2009), and Malaysian (Mahenthiran \& Kasipillai, 2011) markets. Previous studies report mixed results for the relationship between size and ETR. While Siegfried (1972), Porcano (1986), and Richardson \& Lanis (2005) find a negative relationship, Zimmerman (1983) and Rego (2003) report a positive association. Other studies find no significant relationship between size and ETR (e.g., Stickney \& McGee, 1997; Liu \& Cao, 2007). However, Zimmerman (1983) finds a non-monotonic relationship between ETR and firm size that varies by industry and over time. Wilkie \& Limberg (1990) perform a reconciliation of Zimmerman (1983) as well as of Porcano (1986) and argue that the contradicting results can be explained by the different empirical procedures used (i.e., sample selection, time periods, ETR calculations, and proxies for firm size).

More advanced studies include more than one influencing factor in their ETR analysis. Stickney \& McGee (1982) analyze the degree of capital intensity, the extent of foreign operations, the extent of natural resource involvement, and the proportion of debt in the capital structure as factors that may influence ETR. By categorizing firms based on their specific set of values for ten explanatory variables, they conclude that capital intensity, leverage, and natural resource involvement play an important role in explaining differences in firms' ETR. Foreign operations and size appear to be less important. Gupta \& Newberry (1997) also study the link between ETR and firm size as well as capital structure, asset mix, and profitability, but also look at the impact of the United States Tax Reform Act of 1986 (TRA86.) Overall, the results reveal that firms with more inventory and higher profitability tend to have higher ETR, while a higher proportion of fixed assets is associated with lower ETR. The analysis of leverage reveals mixed results depending on the ETR measure used. Leverage appears to be sensitive to different measures of ETR. Gupta \& Newberry (1997) claim that the correlation between size and ETR cannot be shown when firms with longer histories are examined over time. Overall, they conclude that the results of prior univariate studies may be misleading. Rego (2003) analyzes the impact of firm size, pre-tax income, and foreign operations on ETR. She concludes that larger corporations have higher ETR. Moreover, she provides evidence that companies with more foreign operations and higher pre-tax income have lower ETR. All the studies mentioned above analyze US firms.

Investigating Australian firms, Richardson \& Lanis (2007) find an inverse relationship between ETR and firm size before and after a tax reform. They conclude that firm size shows a robust negative association with ETR over time, 
which contradicts the findings of Gupta \& Newberry (1997). More leveraged, R\&D intensive firms and companies with greater proportion of fixed assets appear to have lower ETR. Inventory proportion and profitability show positive coefficients. Liu \& Cao (2007) analyze Chinese companies with regard to the impact of firm size, leverage, capital intensity, firm's earning ability, and ownership structure on ETR. In accordance with Stickney \& McGee (1984) and a recent study by Amstrong et al. (2012), Liu \& Cao (2007) are not able to show a significant correlation between firm size and ETR. While they find a negative relationship between leverage and ETR, capital intensity does not affect ETR. Furthermore, profitability and ownership structure tend to vary with the tax environment. While other studies use pre-tax income or operating cash flows as a denominator when calculating ETR, Liu \& Cao (2007) calculate ETR using EBIT as a denominator. Since interest expenses are tax-deductible, EBIT does not appear to be an accurate proxy.

To my knowledge, Sureth et al. (2009) conduct the only empirical study for German companies using a univariate analysis. They analyze whether foreign operations, leverage, and capital intensity are associated with ETR yet they find no impact of foreign operations on ETR. Overall, their study shows inconsistent results that vary across industries and years. Sureth et al. (2009) use EBIT (as a synonym for operating profit) in the denominator instead of pre-tax income. They argue that ETR is not affected by extraordinary items and irregular interest or dividends when EBIT is used as a denominator. However, since interest expenses are tax-deductible, a measure that accounts for this fact appears more appropriate, such as pre-tax income adjusted for extraordinary items. Moreover, Sureth et al. (2009) use total tax expense, which comprises current and deferred taxes, in the numerator. Therefore, a firm's tax strategy that leads to the recognition of deferred taxes will not affect ETR (Hanlon \& Heitzman, 2010). (Note 1) This may explain the frequent absence of a significant relationship between capital intensity and ETR. They use shareholder capital to total assets as a proxy for leverage and find a positive correlation with ETR. However, these results vary with regard to industry and year. Overall, the results may be driven by the small sample of 123 firms.

Investigating the US Tax Reform Act of 1986 (TRA86), Gupta \& Newberry (1997) find that the tax reform significantly impacted the association of ETR and firm-specific characteristics and that these associations continued after TRA86. Analyzing the effects of the Australian Ralph Review of Business Taxation reform, Richardson \& Lanis (2007) find a declining ETR and that firm-specific factors are significantly affected by the tax reform. They conclude that firm characteristics remain associated with ETR after the tax reform.

Prior literature also analyzes tax planning activities of firms (e.g., Frank et al., 2009; Chen et al., 2010; Wahab \& Holland, 2012). There is an extensive literature on how taxes affect firm's decision making and firm value (see Graham, 2003, for literature review). However, since there is nearly no empirical literature on German ETR, this study aims to close the gap in the literature by analyzing the factors that drive ETR of German listed companies using panel data. Moreover, this paper analyzes the impact of GTR08 on ETR and its effect on the association between firm-specific factors and ETR after the tax reform.

\section{Hypothesis Development}

To test which firm characteristics affect ETR, hypotheses are developed that are grouped into

a) ETR and Firm Size,

b) ETR and Firms' Financing and Investment Decisions,

c) ETR and Other Firm-Specific Characteristics, and

d) ETR and Germany's Corporate Tax Reform 2008

a) ETR and Firm Size

There are two competing theories about the relationship between firm size and ETR. The political power theory holds that larger firms have an incentive to shape the political process in their favor. In this regard, Siegfried (1972) posits that larger firms ought to have lower ETR for three reasons. First, larger firms have greater resources to influence the political process in ways that will benefit them. Second, they become experts at tax planning, with some larger firms in a better position to hire tax experts (with more expertise). Third, they optimize their activities to achieve the highest possible tax savings.

In contrast to the political power theory, Jensen \& Meckling (1976) argue that companies are subject to political pressure. Under the political cost theory, larger and more profitable firms have greater public visibility, which encourages the government to take regulatory action that is disadvantageous for these firms in order to achieve a transfer of wealth (Zimmermann, 1983; Watts \& Zimmerman, 1990). Influential voters may lobby for wealth transfer by advocating, for example, social responsibility, more regulation, divestiture, or higher corporate taxes (as a method 
of transferring wealth away from the firm). Taxes are part of the total political cost that firms must absorb. Thus, the political cost theory argues that larger firms have higher ETR due to the political cost of visibility.

As discussed in Section 2, previous research shows inconsistent results for the relationship between firm size and ETR. While some studies report a negative relationship (e.g., Siegfried; 1972; Porcano, 1986; Richardson \& Lanis, 2005), others find a positive relationship (e.g., Zimmerman, 1983; Rego, 2003) or no relationship at all (e.g., Stickney \& McGee, 1997; Liu \& Cao, 2007). However, as argued by Wilkie \& Limberg (1990) and Gupta and Newberry (1997), the mixed results may be due to different samples, time periods and proxies for ETR and size. I am not aware of any study that investigates the impact of firm size on ETR of German listed firms. Sureth et al. (2009) do not include a proxy for size in their study. Due to the inconsistent results of previous studies, the expectation is that firm size affects ETR but that there is no relationship between the two measures.

\section{H1: ETR is associated with firm size.}

\section{b) ETR and Firms' Financing and Investment Decisions}

With reference to agency theory and its implications for a firm's capital structure, this paper argues that increasing a firm's leverage puts the interests of the management and shareholders into alignment through, e.g., debt covenants. Through these covenants in borrowing agreements, managers are typically forced to negotiate future investments with their lenders and therefore it becomes more difficult to pursue negative net present value projects. Accordingly, the firm becomes more efficient. The increased efficiency and the alignment of interests between the otherwise contradicting parties (agent and principal) will ultimately result in lower ETR.

Usually, Germany is considered a bank-oriented country. In these countries companies are expected to rely more on debt than on equity financing. Rajan \& Zingales (1995) analyze the capital structure in different countries and find that, on average, German firms are relatively less levered compared to those in other G7 countries. But, small and mid-size firms are significantly more levered compared to larger companies. However, a more recent study of Rajan \& Zingales (2003) suggest that the European financial system has become more market-based. Firms' financing decisions are likely to impact ETR because tax regulations treat expenses associated with capital structure differently. Interest expenses are usually tax-deductible, while dividends are not. Since the German tax reform in 2008 (GTR08), interest expenses has been tax-deductible as long as the interest paid does not exceed the interest income received in the same year by more than $30 \%$ of EBITDA or $€ 3 \mathrm{~m}$. Overall, the expectation is that firms with higher leverage have lower ETR. Hence, the second hypothesis is:

\section{H2: ETR is negatively associated with firm leverage.}

The use of accounts from the balance sheet reflects only the impact of financing decisions that result in a definition of firm's liability. Leasing is a form of financing comprising two types of lease, finance leases and operating leases. Usually, financing decisions are associated with either debt or equity financing. However, if a firm decides to lease an asset and the lease is classified as a finance lease, the present value of the liability would be recognized on the entity's balance sheet. Hence, finance leases are incorporated in the measure of leverage, such as debt to equity or debt to assets. Since operating leases are not recognized by the lessee, they are not included in the calculation of leverage. Nelson et al. (2002) report that firms' structure transactions can have tax effects (e.g., leases). However, rent/operating leases are tax-deductible and therefore should influence the ETR. The expectation is that firms with higher rent/operating lease expenses have lower ETR.

\section{H3: ETR is negatively associated with rent/operating lease expenses.}

To calculate ETR, the ratio of total income tax expense to pre-tax income is used. Total income tax expense comprises current and deferred taxes. Deferred taxes capture the tax effects resulting from differences between book and tax accounts. Therefore, differences in the capital intensity of firms should not affect ETR. For instance, if tax regulations allow for higher depreciation, firms with higher proportion of fixed assets would have lower ETR. Since firms need to account for book-tax differences, the difference between lower tax accounts and higher book values of fixed assets would result in a deferred tax liability and therefore increase the total tax expense. Generally speaking, strategies that result in deferred taxes would have no impact on ETR. However, capital-intensive firms have more opportunities for tax planning or tax-avoidance strategies than other firms. For instance, they can decide whether to buy or lease assets. This analysis accounts for this by including leverage as well as operating leases. The firms can also time the purchase of goods or the lease them, for tax purposes, for instance to defer or to accelerate losses (Mills et al., 1998). However, the untabulated results show no significant relationship between the proxy for capital intensity (property, plant, and equipment to total assets) and ETR. All other findings are similar to the results 
reported in Section 5. It appears that the mixed structure has no impact on ETR when it accounts for deferred taxes. Therefore, no proxies for capital intensity are included in the regressions reported in this study.

\section{c) ETR and Other Firm-Specific Characteristics}

Jensen (1986) develops a theoretical link between agency theory and the payout of cash to shareholders. The entity's resources, which are under the control of managers (agents of shareholders), decrease with the cash payouts to shareholders. Hence, the managers' power declines with higher payouts and the managers are likely to be monitored by the capital market when they issue new capital. By keeping free cash flow within the company, debt as a source of capital for its operations becomes less important to the agent. In this regard, free cash flow would release management from the tight monitoring obligations imposed by the lenders, giving them the freedom to use the cash for the projects they desire, even though they may be unprofitable. In pursuit of this so-called empire building, the agent may invest cash in projects with a negative net present value. The fact that an agent can prevent the distribution of firm's free cash flow may indicate the presence of an information asymmetry, since a principal is obviously not able to monitor the agent in a way that would deter the accumulation of free cash flow. In addition, increases in free cash flow exacerbate information asymmetries, since an agent in a company with robust free cash flow would not be subject to the same restrictive covenants as a highly leveraged company. The combination of agency theory suggests that the accumulation of free cash flow leads to a mismatch between the agent's interests and those of the shareholder. Thus, the agent will reduce its efforts to maximize the shareholder's wealth and to reduce the firm's ETR, as this would be in the best interest of the shareholders. This would result in a positive relationship between ETR and FCF.

On the other hand, managers act according to their utility function which does not necessary counteract the shareholder's interests. Taxes are paid to a third party and reduce the funds under manager's control. Therefore, managers try to reduce tax payments to keep more cash inside the company. Hence, principal's and agent's incentives to reduce taxes are aligned. This leads to a negative relationship between ETR and FCF. Overall, the expectation is that FCF influences ETR. However the direction is not predicted.

\section{H4: ETR should be associated with a firm's free cash flow.}

Germany imposes taxes on worldwide income and limits a taxpayer's ability to offset foreign income taxes (by restricting foreign tax credits). If firms operate in countries with a lower tax rate than in Germany, worldwide ETR will likely be lower than for firms that operate in high-tax countries or domestic-only companies. Compared to domestic-only firms, multinational companies have more opportunities for tax savings. They can strategically exploit differences in tax rules and tax rates by shifting income between the countries where they maintain a presence. They can shift operations to low-tax countries and engage in capital and product flow transactions with foreign countries. Previous literature shows that foreign operations have a significant negative impact on ETR and on tax strategies (e.g., Mills et al., 1998; Rego, 2003; Markle \& Shackelford, 2010). By contrast, Sureth et al. (2009) conclude that foreign operations do not affect German firms' ETR. Germany still places a relatively high tax burden on corporate profits. Therefore, it is assumed that multinational firms will try to exploit tax-reducing strategies, which produces a negative association between ETR and foreign operations.

\section{H5: ETRs are negatively associated with a firm's foreign operations.}

With regard to firm life cycle and price-to-book ratio (P/B), firms are grouped into growth stocks and mature/value stocks, among others (e.g., Grullon et al., 2002; Fama \& French, 2007; Dickinson, 2011). Growth and mature firms vary in terms of their profitability, cash flow, dividend payout, growth, risk, and investment strategies. Fama \& French (2007) differentiate between growth firms in the top $30 \%$ of $\mathrm{P} / \mathrm{B}$, neutral stocks in the middle $40 \%$ of $\mathrm{P} / \mathrm{B}$, and value firms in the bottom 30\% of P/B. Mohanram (2005) and Fama \& French (2007) associate growth firms with a higher profitability than mature stocks. Grullon et al. (2002) claim that growth firms have high capital expenditures, low free cash flow, large economic profits, rapid growth in earnings, and higher profitability than mature firms. Growth firms are characterized by a smaller amount of foreign direct investment that would result in higher ETR. Overall, a complex picture emerges regarding the possible association with ETR for growth and mature firms. If it is highly valued by the stock market, a firm may be less keen to reduce its tax burden, but may make more of an effort to maintain or increase its stock price. Furthermore, Dickenson (2011) and Grullon et al. (2002) argue that growth firms are associated with higher leverage than mature stocks because they need more capital for investments purposes. This leads to higher interest costs, which are tax-deductible. Overall, because they concentrate less on tax avoidance, growth stocks are expected to have higher ETR.

H6a: Growth firms are positively associated with ETR. 
The lower profitability of mature stocks can be associated with lower ETR because there is less taxable income. Furthermore, Rego (2003) argues that if management believes that a company's tax burden is reflected in stock prices and investors see taxes as a measure of performance, management would engage in tax avoidance strategies to increase the company's market value. Hence, there would be a negative relationship between ETR and undervalued firms. On the other hand, less leverage reduces tax deductions, which can result in higher ETR. Since it is assumed that there are differences between growth and mature firms, an opposite relationship is expected for the latter.

\section{H6b: Mature firms have lower ETR.}

The proxies for size, FCF, and mature and growth firm may capture differences in profitability. The measure of profitability (return on assets, ROA) is directly included in the regression to investigate its impact on ETR. Based on Wilkie (1988), Gupta \& Newberry (1997) decompose the measure of ETR and show a positive relationship between the ETR and ROA variables. The prior literature reports a positive relationship between profitability and ETR (e.g., Richardson \& Lanis, 2005; Liu \& Cao, 2007; Armstrong et al., 2012). Hence, it appears that more profitable firms have higher ETR. However, Manzon \& Plesko (2002) argue that managers may want to increase accounting income and at the same time reduce taxable income. Rego (2003) and Mahenthiran \& Kasipillai (2011) claim that more profitable firms may have more incentives and opportunities to reduce their tax burden through tax deductions and hence are more engaged in tax avoidance strategies. Mahenthiran \& Kasipillai (2011) argue that profitable firms are likely to engage in aggressive tax planning because of their growing free cash flows and their focus on measuring operating income using accrual rather than cash flow methods. Their results show that profitable firms engage more in aggressive tax planning. Overall, profitability is expected to have an effect on ETR. However, no predictions are made as to the direction of the relationship.

H7: Profitability is associated with ETR.

d) ETR and Germany's Corporate Tax Reform 2008

The key purposes of Germany's Corporate Tax Reform 2008 are the increase in attractiveness of investments in Germany and certainty in tax revenue. The overall tax rate for corporations decreases from $38.6 \%$ to $29.83 \%$ and the German legislature broads the tax base by limiting deductions of interest expenses, rents, and leases, and abolishing the declining depreciation (Bundesrat, 2007; Kessler \& Eicke, 2007). The tax base-broadening changes are expected to have different effects on firm's ETR depending on the individual firm characteristics. For instance, more interest intense firms should be more affected by the changes than less interest intense corporations. On the one hand the reduction in corporate and trade tax rates should decrease firm's ETR, on the other hand the base-broadening reforms could increase the ETR. However, I expect that the reduction in tax rates overcompensates the limitations of deductions from the tax base resulting a negative relationship between GTR08 and ETR.

\section{H8: Germany’s Corporation Tax Reform 2008 is negatively associated with ETR.}

GTR08 could impact the association of firm characteristics and ETR. It is probable that the relationship between ETR and firm's financing decisions is effected after GRT08. Since the tax reform limits the deductions of interest and lease expenses, these associations should be significantly impacted by GTR08. The average effect of GTR08 on the relationship between leverage and ETR is not clear. While the tax rates are reduced, the limitation of interest deductions may increase firm's ETR. However, for more levered firms, I expect that the association between leverage and ETR is positively affected by GTR08. Following the same argumentation, I expect that GTR08 positively impacts the relationship between rent/operating leases and ETR.

H9: For more levered firms, the association between leverage and ETR is positively affected by GTR08.

H10: For more rent/operating lease intensive firms, the association between leverage and ETR is positively affected by GTR08.

Since it is not directly clear how the relationship between other firm characteristics and ETR may be effected by the GTR08, I do not predict the effects.

\section{Research Design and Sample Selection}

\subsection{Definition of Variables}

\subsubsection{Dependent Variable}

As the parameters "tax burden" and "measure of income" are interpreted differently in the literature, they require further definition. According to IAS 12.86, the calculation of the average effective tax rate has tax expense (income) as the numerator and accounting profit as the denominator. Current income taxes reflect taxes actually paid. Deferred 
taxes represent the impact of differences between the financial balance sheet and the tax balance sheet on taxation. Deferred taxes are payable in future periods. Some studies use current tax expense in the nominator (e.g., Gupta \& Newberry, 1997; Rego, 2003; Liu \& Cao, 2007), others include deferred taxes (e.g., Sureth et al., 2009; Mahenthiran \& Kasipillai, 2011; Amstrong et al., 2012). Omitting deferred taxes can significantly bias the overall tax burden. This paper follows more recent studies and uses total income tax expenses as the nominator.

Accounting earnings computation cannot normally perfectly measure true economic or taxable income. The denominator is obtained through the financial statements and does not necessarily match the tax assessment base. Since real taxable income is computed by the tax authorities and is not publicly obtainable, the denominator must be replaced by another figure that closely approximates real taxable income. Prior studies use various denominators to calculate the ETR. For instance, Liu \& Cao (2007) and Sureth et al. (2009) use EBIT. As discussed in Section 2, this measure ignores the fact that interest expenses are deductible from the tax base. Other studies use pre-tax income (e.g., Rego, 2003; Mahenthiran \& Kasipillai, 2011; Amstrong et al., 2012). Due to the disadvantages of using EBIT in Section 2, ETR is calculated here as total tax expense scaled by pre-tax income. The effective tax rate is calculated as follows:

$$
E T R_{i t}=\frac{\text { Total income expense }_{i t}}{\text { pre-tax income }}
$$

where $t$ stands for the year and $i$ for the firm. ETR is the effective tax rate calculated as total income expense (Datastream item "WC01451") that comprises current and deferred tax expense scaled by pre-tax income (Datastream item "WC01401"). ETR is constrained to lie between $0 \%$ and $100 \%$. Following Gupta and Newberry (1997) and Schmidt (2006), ETR is set to $0 \%$ if the total income tax expense is negative (tax refunds) and to $100 \%$ if the pre-tax income is negative and the total income tax expense greater than 0 .

As discussed by Hanlon \& Heitzman (2010), this measure of ETR reflects only non-conforming tax avoidance. Hence, it does not capture tax strategies that result in lower accounting earnings and lower taxable income.

\subsubsection{Independent Variables}

Proxies are used for size, leverage, operating lease expenses, free cash flow, and profitability as firm-specific characteristics. Moreover, the analysis differentiates between growth and mature firms and calculates the natural logarithm of total assets (Datastream item "WC02999") as a proxy for firm size (SIZE). The capital structure (LEVERAGE) is represented by the ratio of long-term debt to shareholders' equity (Datastream item "WC03251" scaled by Datastream item "WC03995"). OL represents the rental/operating lease expenses scaled by sales (Datastream item "WC18140" divided by Datastream item "WC01001"). Free cash flow is the difference between operating cash flow, capital expenditures, and dividends paid (Datastream item "WC04860" less Datastram item "WC04601" less Datastream item "WC04551"). The variable FCF is free cash flow, as described above, scaled by total assets (Datastream item "WC02999"). ROA is return on assets (Datastream item "WC08326"). Not all companies report their foreign sales. However, if firms do not report foreign sales, they may not have foreign operations, or their foreign sales account for a negligible part of their overall sales. If foreign sales are not reported, they are replaced by 0 . To investigate the impact of foreign operations, the variable FOREIGN is used, which is represented by foreign sales (Datastream item "WC07101") scaled by total sales (Datastream item "WC01001"). To ensure the results are robust, the analysis follows Rego (2003) and uses a dummy variable (FOREIGNDUM) that equals 1 if foreign sales are reported, and 0 otherwise. The price-to-book ratio $(\mathrm{P} / \mathrm{B})$ is calculated by market capitalization (Datastream item "WC08001") scaled by shareholders' equity (Datastream item "WC03995") for each industry individually. A company is considered a growth firm if its $\mathrm{P} / \mathrm{B}$ is in the top $30 \%$ of industry-specific $\mathrm{P} / \mathrm{B}$ (GROWTH). If the firm is in the bottom $30 \%$ of its industry-specific $\mathrm{P} / \mathrm{B}$, the company is classified as a mature firm (MATURE). I include the dummy variable TR08 that equals 1 for periods after the tax reform $(2008-2011)$, and 0 otherwise. I interact the TR08 with firm characteristics described above to analyze the impact of GTR08 on their associations with ETR. To analyze the impact of GTR for more and less levered firms, I also include two dummy variables LEVERAGE high and LEVERAGE_low. LEVERAGE_high (LEVERAGE_low) equals one if LEVERAGE is higher (lower) than the $75^{\text {th }}\left(25^{\text {th }}\right)$ percentile, and zero otherwise. The definitions of variables are summarized in Table 1. 
Table 1. Definition of variables

\begin{tabular}{|c|c|}
\hline ETR & $\begin{array}{l}\text { Effective tax rate, income taxes (Datastream item "WC01451") scaled by pre-tax } \\
\text { income (Datastream item "WC01401") }\end{array}$ \\
\hline SIZE & Firm size, natural logarithm of total assets (Datastream item “WC02999”) \\
\hline LEVERAGE & $\begin{array}{l}\text { Leverage, long-term debt (Datastream item “WC03251") scaled by shareholders' equity } \\
\text { (Datastream item "WC03995”) }\end{array}$ \\
\hline $\mathrm{OL}$ & $\begin{array}{l}\text { Operating lease expense, rent/operating lease expenses (Datastream item "WC18140") } \\
\text { scaled by sales (Datastream item "WC01001") }\end{array}$ \\
\hline $\mathrm{FCF}$ & $\begin{array}{l}\text { Free cash flow, operating cash flow minus capital expenditures minus dividends paid } \\
\text { (Datastream item "WC04860" less Datastram item "WC04601" less Datastream item } \\
\text { "WC04551") scaled by total assets (Datastream item "WC02999") }\end{array}$ \\
\hline ROA & Return on assets (Datastream item "WC08326”) \\
\hline FOREIGN & $\begin{array}{l}\text { Foreign sales ratio, foreign sales (Datastream item "WC07101") scaled by total sales } \\
\text { (Datastream item "WC01001") }\end{array}$ \\
\hline FOREIGNDUM & $\begin{array}{l}\text { Dummy variable equals } 1 \text { if a firm reports foreign sales (Datastream item "WC07101"), } \\
0 \text { otherwise }\end{array}$ \\
\hline $\mathrm{P} / \mathrm{B}$ & $\begin{array}{l}\text { Price-to-book ratio, market capitalization (Datastream item "WC08001") divided by } \\
\text { total shareholders' equity (Datastream item "WC03995") }\end{array}$ \\
\hline GROWTH & $\begin{array}{l}\text { Dummy variable equals } 1 \text { if the firm is in the top } 30 \% \text { of } \mathrm{P} / \mathrm{B} \text { on an industry basis; } 0 \\
\text { otherwise, where P/B is calculated by market capitalization (Datastream item } \\
\text { "WC08001") divided by shareholders' equity (Datastream item "WC03995") }\end{array}$ \\
\hline MATURE & $\begin{array}{l}\text { Dummy variable equals } 1 \text { if the firm is in the bottom } 30 \% \text { of } \mathrm{P} / \mathrm{B} \text { on industry basis and } 0 \\
\text { otherwise, where } \mathrm{P} / \mathrm{B} \text { is calculated by market capitalization (Datastream item } \\
\text { "WC08001") divided by shareholders' equity (Datastream item "WC03995") }\end{array}$ \\
\hline TR08 & Dummy variable equals 1 for the post-tax reform period $(2008-2011), 0$ otherwise \\
\hline LEVERAGE_high & Dummy variable equals 1 if LEVERAGE is higher than $75^{\text {th }}$ percentile, 0 otherwise \\
\hline LEVERAGE_low & Dummy variable equals 1 if LEVERAGE is lower than $25^{\text {th }}$ percentile, 0 otherwise \\
\hline
\end{tabular}

Note: The table describes the variables used in the paper.

\subsection{Sample Selection and Research Method}

The sample consists of firms drawn from the Datastream database between 2005 and 2011. The study is based on data on German companies (Note 2) which report according to IFRS. Following prior research (e.g., Gupta \& Newberry, 1997; Richardson \& Lanis, 2007), financial institutions and insurances are excluded because of regulatory constraints in these industries. This results in a sample of 540 firms. ETR is constrained to lie between $0 \%$ and $100 \%$. Observations with missing regression variables are eliminated. A fixed effects model is used. Each firm is required to have at least two observations. After all exclusions, the final sample comprises 487 firms $(2,731$ observations).

Due to the panel structure of the data, it is possible to include unobservable information that is hidden both in the cross-section as well as in the time dimension of the data. The fixed effects model (FEM) considers that individual unobservable effects may be correlated with the explanatory variables. The FEM controls for time-invariant variables (unobserved heterogeneity) and the individual effects are jointly estimated with the coefficients. Under the random effects model (REM), the individual effects are incorporated into the error term and assumed to be uncorrelated with the independent variables. The REM allows for the inclusion of the time-invariant variables into the regression. However, if the individual effects are correlated with explanatory variables, the estimator would be inconsistent. Yet the Wooldridge test and the Arellano-Bond test reveal autocorrelation in the data. Moreover, the modified Wald test reveals heteroscedasticity in the residuals. We control for autocorrelation, heteroscedasticity and possible correlation between groups using Driscoll \& Kraay (1998) standard errors for coefficients estimated by the within-group estimator. Using the within-group estimator, observations of the mean difference of a time-invariant variable are zero. Hence, coefficients for time-invariant variables cannot be estimated. Dummy variables such as industry dummies would be eliminated since their mean over time is one.

With regard to the robustness checks of the results reported below, the dummy variable FOREIGN equals 1 if the firm reports foreign sales and 0 otherwise. If a firm reports (no) foreign sales for every year under review, the mean of the dummy variable FOREIGNDUM is $1(0)$ and therefore dropped when calculating the coefficient. There are 30 companies that started to report foreign sales during the period 2005-2011 and therefore the dummy variable 
switches from 0 to 1 . The coefficient of FOREIGNDUM captures the systematic differences between these companies and the remaining sample. Moreover, following Dhaliwal et al. (2004), foreign operations are scaled by pre-tax income to investigate the effect of foreign operations.

The time effects of the error term are captured by year dummies. Since the analysis covers firms that are all listed on the German capital market, the time dummies also capture the macroeconomic effects. Each variable is winsorized at the $1 \%$ and $99 \%$ levels to mitigate the effects of outliers. The joint significance of reported coefficients and the joint significance of year dummies is investigated separately using Wald tests. The regression model to analyze which firm characteristics affect the ETR is as follows:

$$
\begin{aligned}
\text { ETR }_{i t}= & \beta_{0}+\beta_{1} \text { SIZE }_{i t}+\beta_{2} \text { LEVERAGE }_{i t}+\beta_{3} O L_{i t}+\beta_{4} \text { FCF }_{i t}+\beta_{5} \text { ROA }_{i t}+\beta_{6} \text { FOREIGN }_{i t}+\beta_{7} \text { GROWTH }_{i t} \\
& +\beta_{8} \text { MATURE }_{i t}+\eta_{i}+d_{t}+\varepsilon_{i t}
\end{aligned}
$$

where $i$ relates to firm $(\mathrm{i}=1 \ldots \mathrm{N})$ and $t$ to the time period $(2006-2011), \eta_{i}$ denotes the individual effect, $d_{t}$ a time-specific effect, and $\varepsilon_{i t}$ is the random disturbance. The definitions of variables for the equation are summarized in Table 1.

To investigate the effect of GTR08 on ETR and whether the tax reform impacts the relationship between firm characteristics and ETR, I include the dummy variable TR08 and the interaction terms, following Richardson \& Lanis (2007).

$$
\begin{aligned}
\text { ETR }_{i t} & =\beta_{0}+\beta_{1} \text { SIZE }_{i t}+\beta_{2} \text { LEVERAGE }_{i t}+\beta_{3} \text { OL }_{i t}+\beta_{4} \text { FCF }_{i t}+\beta_{5} \text { ROA }_{i t}+\beta_{6} \text { FOREIGN }_{i t}+\beta_{7} \text { GROWTH }_{i t} \\
& +\beta_{8} \text { MATURE }_{i t}+\beta_{9} \text { TR08 }_{i t} * \text { SIZE }_{i t}+\beta_{10} \text { TRO8 }_{i t} * \text { LEVERAGE }_{i t}+\beta_{11} \text { TR08 }_{i t} * O L_{i t} \\
& +\beta_{12} \text { TR08 }_{i t} * \text { FCF }_{i t}+\beta_{13} \text { TR08 }_{i t} * \text { ROA }_{i t}+\beta_{14} \text { TR08 }_{i t} * \text { FOREIGN }_{i t}+\beta_{15} \text { TR08 }_{i t} * \text { GROWTH }_{i t} \\
& +\beta_{16} \text { TR08 }_{i t} * \text { MATURE }_{i t}+\eta_{i}+d_{t}+\varepsilon_{i t}
\end{aligned}
$$

The dummy variable TR08 reflects the mean effect of Germany's tax reform of 2008 on ETR. The coefficients of firms-specific characteristics present the association with ETR before the tax reform, the interaction terms show whether GTR08 had an effect on these associations. I also calculate the sum of individual firm-characteristic and its interaction term (e.g., firm's size: $\beta_{1}+\beta_{9}$ ), which reflects the association with ETR in the post-tax reform period. To analyze the effect of GTR08 on more (less) levered firms only I restrict the sample to observations where LEVERAGE is higher (lower) than the $75^{\text {th }}\left(25^{\text {th }}\right)$ percentile using equation 3 . To robust the results, I also analyze the impact of GTR08 for more and less levered firms including interaction terms with two dummy variables LEVERAGE_high and LEVERAGE_low.

$$
\begin{aligned}
\text { ETR }_{i t}= & \beta_{0}+\beta_{1} \text { SIZE }_{i t}+\beta_{2} \text { LEVERAGE }_{i t}+\beta_{3} \text { OL }_{i t}+\beta_{4} \text { FCF }_{i t}+\beta_{5} \text { ROA }_{i t}+\beta_{6} \text { FOREIGN }_{i t}+\beta_{7} \text { GROWTH }_{i t} \\
& +\beta_{8} \text { MATURE }_{i t}+\beta_{9} \text { TRO8 }_{i t} * \text { SIZE }_{i t}+\beta_{10} \text { TRO8 }_{i t} * \text { LEVERAGE }_{\text {low }} \text { it } \\
& +\beta_{11} \text { TR08 }_{i t} * \text { LEVERAGE }_{\text {high }}+\beta_{12} \text { TR R }_{i t} * \text { OL }_{i t}+\beta_{13} \text { TR08 }_{i t} * \text { FCF }_{i t}+\beta_{14} \text { TR08 }_{i t} * \text { ROA }_{i t} \\
& +\beta_{15} \text { TR08 }_{i t} * \text { FOREIGN }_{i t}+\beta_{16} \text { TR08 }_{i t} * \text { GROWTH }_{i t}+\beta_{17} \text { TRO8 }_{i t} * \text { MATURE }_{i t}+\eta_{i}+d_{t}+\varepsilon_{i t}
\end{aligned}
$$

\section{Results}

\subsection{Descriptive Statistics}

Table 2 presents summary statistics for ETR for the period 2005-2011 and for each year individually. The aggregated mean (median) ETR is 33\% (29\%). The German tax reform in 2008 reduced the statutory tax rate from approximately $39 \%$ to approximately $30 \%$. However, using accounting pre-tax income as the denominator shows higher ETR. The yearly mean ranges from $30 \%$ in 2006 and in 2010 to $36 \%$ in 2008 . However, the descriptive statistics show the highest ETR (36\%) in 2008. Since an accounting measure is used as the denominator, ETR is influenced by accounting choices. The 2008/2009 financial crisis is likely to have had significant effects on ETR. The reduced pre-tax income may have overcompensated for the reduction in income taxes. In terms of industry, the analysis reveals the highest mean ETR for wholesale trade (25\%) and the lowest ETR for agriculture, forestry, and fishing (21\%) for the period 2005-2011 (results not reported here). Over the period 1999-2006, Sureth et al. (2009) report a mean ETR of $32 \%(30 \%)$. 
Table 2. Descriptive statistics for the dependent variable

\begin{tabular}{lcccccccc}
\hline & Mean & $\begin{array}{c}\text { Standard } \\
\text { Deviation }\end{array}$ & $\begin{array}{c}\text { Percentile } \\
\text { 25 }\end{array}$ & Median & Percentile & Min & Max & N \\
\hline ETR (2005-2 011) & 0.33 & 0.3 & 0.09 & 0.29 & 0.39 & 0 & 1 & 2,731 \\
ETR (pre-tax reform period) & 0.32 & 0.29 & 0.08 & 0.30 & 0.40 & 0 & 1 & 1,179 \\
ETR (post-tax reform period) & 0.33 & 0.31 & 0.09 & 0.29 & 0.37 & 0 & 1 & 1,552 \\
ETR (2005) & 0.35 & 0.3 & 0.11 & 0.33 & 0.42 & 0 & 1 & 352 \\
ETR (2006) & 0.3 & 0.29 & 0.02 & 0.28 & 0.39 & 0 & 1 & 404 \\
ETR (2007) & 0.32 & 0.28 & 0.11 & 0.3 & 0.39 & 0 & 1 & 423 \\
ETR(2008) & 0.36 & 0.32 & 0.17 & 0.3 & 0.41 & 0 & 1 & 415 \\
ETR (2009) & 0.31 & 0.33 & 0 & 0.27 & 0.37 & 0 & 1 & 390 \\
ETR (2010) & 0.3 & 0.29 & 0.1 & 0.28 & 0.35 & 0 & 1 & 388 \\
ETR (2011) & 0.34 & 0.3 & 0.16 & 0.29 & 0.36 & 0 & 1 & 359 \\
\hline
\end{tabular}

Notes: Table 2 presents descriptive statistics for the effective tax rate (ETR), which is calculated by total tax expense scaled by pre-tax income for the overall period, pre- and post-tax reform period, and on a yearly basis. The sample comprises 487 firms with 2,731 firm-year observations over 2005-2011.

Table 3 presents descriptive statistics for the explanatory variables. Total assets range from $€ 3 \mathrm{~m}$ to $€ 51,500 \mathrm{~m}$. The sample covers a broad range of sizes but reflects small means and medians $(€ 1,901 \mathrm{~m}$ and $€ 121 \mathrm{~m}$, respectively). The mean (median) of LEVERAGE is $0.358(0.133)$. The ratio of foreign sales scaled to total sales (FOREIGN) reveals a strong variation from 0.000 to 0.993 with a mean (median) of $0.326(0.279)$. There are firms that generate nearly all of their profits through foreign operations. Summary statistics and calculated skewness expose a skewed distribution to the right (positively skewed). Since firm-specific characteristics are analyzed, the distribution has no implications for our analysis.

Table 3. Descriptive statistics of explanatory variables

\begin{tabular}{lcccccccc}
\hline & Mean & $\begin{array}{c}\text { Standard } \\
\text { Deviation }\end{array}$ & Percentile 25 & Median & $\begin{array}{c}\text { Percentile } \\
75\end{array}$ & Min & Max & N \\
\hline Total assets, $€ m$ & 1,901 & 7,177 & 40 & 121 & 491 & 3 & 51,500 & 2,731 \\
\hline LEVERAGE & 0.358 & 1.227 & 0.003 & 0.133 & 0.508 & -6.145 & 7.549 & 2,731 \\
\hline OL & 0.020 & 0.041 & 0.000 & 0.007 & 0.022 & 0.000 & 0.299 & 2,731 \\
\hline FCF & -0.012 & 0.141 & -0.044 & 0.014 & 0.057 & -0.679 & 0.262 & 2,731 \\
\hline FOREIGN & 0.326 & 0.313 & 0.000 & 0.279 & 0.602 & 0.000 & 0.993 & 2,731 \\
\hline ROA & 1.991 & 15.747 & 0.910 & 4.720 & 8.520 & -76.160 & 35.960 & 2,731 \\
\hline
\end{tabular}

Notes: Table 3 presents descriptive statistics for selected explanatory variables included in the regression analyses for longitudinal data using ETR. The sample comprises 487 firms with 2,731 firm-year observations over 2005-2011. All variables are winsorized at the $1^{\text {st }}$ and $99^{\text {th }}$ percentile. The variables are as defined in Table 1.

\subsection{Spearman Correlations}

Using the Shapiro-Wilk test, the normality of variables used in this paper is rejected. Therefore, Spearman's rank correlation coefficients for ETR and the explanatory variables are reported in Table 4. Spearman's rho shows a positive and significant correlation between ETR and SIZE, supporting the political cost theory. As expected, a negative and significant correlation is found between OL and ETR. However, Spearman's rho is positive for LEVERAGE and the proxies for the foreign operations. The results show that higher ROA is associated with lower ETR. Moreover, while mature firms appear to have lower ETR, growth firms are associated with higher ETR.

Moreover, it appears that larger firms are more profitable, are associated with higher leverage and profitability, and have more foreign operations showing positive coefficients. GROWTH is positively associated with FCF and ROA. There may be some collinearity problems between the proxies for foreign operations and SIZE (MATURE and 
GROWTH) because Spearman's rho is greater than $0.5(-0.4)$. We check for multicollinearity by calculating the variance inflation factor. The values are less than 2 . Hence, there are no concerns regarding collinearity.

Table 4. Spearman's rank correlations

\begin{tabular}{|c|c|c|c|c|c|c|c|c|c|c|}
\hline & ETR & SIZE & LEVERAGE & $\mathrm{OL}$ & FCF & FOREIGNDUM & FOREIGN & ROA & MATURE & GROWTH \\
\hline$\overline{\text { ETR }}$ & 1 & & & & & & & & & \\
\hline SIZE & $0.0714 *$ & 1 & & & & & & & & \\
\hline LEVERAGE & $0.0392^{*}$ & $0.4054 *$ & 1 & & & & & & & \\
\hline $\mathrm{OL}$ & $-0.0743^{*}$ & $-0.0458^{*}$ & -0.0071 & 1 & & & & & & \\
\hline FCF & 0.0124 & $0.1289^{*}$ & -0.0105 & -0.0242 & 1 & & & & & \\
\hline FOREIGNDUM & $0.0439^{*}$ & $0.5251^{*}$ & $0.1352^{*}$ & -0.0243 & $0.0871^{*}$ & 1 & & & & \\
\hline FOREIGN & $0.0444 *$ & $0.5614^{*}$ & $0.1803 *$ & $-0.0422 *$ & $0.0719^{*}$ & $0.8413^{*}$ & & 1 & & \\
\hline ROA & $-0.1199 *$ & $0.1689^{*}$ & $-0.0544^{*}$ & $-0.0541 *$ & $0.4075^{*}$ & $0.1262 *$ & $0.0889^{*}$ & & 1 & \\
\hline MATURE & $-0.0526^{*}$ & $-0.1066^{*}$ & $-0.0835^{*}$ & 0.0017 & $-0.1068^{*}$ & $-0.0418^{*}$ & $-0.0608 *$ & $-0.2800^{*}$ & 1 & \\
\hline GROWTH & $0.0480^{*}$ & 0.0126 & 0.0224 & -0.0305 & $0.0327^{*}$ & 0.0292 & $0.0335^{*}$ & $0.1914 *$ & $-0.4265^{*}$ & 1 \\
\hline
\end{tabular}

Notes: Table 4 presents the Spearman correlations for ETR of 487 firms with 2,731 observations. The variables are as defined in Table 1 . All continuous variables are winsorized at the $1^{\text {st }}$ and $99^{\text {th }}$ percentile. $*$ indicates significant Spearman coefficients at two-sided $p$-value $\leq 0.10$.

\subsection{Regression Results}

Table 5 reports the regression results from Equation (2) using a fixed-effects model by calculating a within-group estimator with Driscoll \& Kraay (1998) standard errors, which accounts for autocorrelation and heteroscedasticity. The $p$-values of the coefficients are reported in parentheses. A Wald test is used for the joint significance of reported coefficients, which tests whether the parameters associated with explanatory variables are zero. A Wald test of the joint significance of the year dummies is also reported.

A positive and significant coefficient emerges for SIZE $(\beta=0.026$, sig $=0.072)$. The findings show a significant relationship as expected in hypothesis $1(H 1)$ and is consistent with Spearman correlation coefficients, supporting the political cost theory. In accordance with Zimmerman (1983) and Rego (2003), this indicates that larger firms have higher ETR. LEVERAGE has a negative and significant association with ETR $(\beta=-0.014$, sig $=0.044)$. This result is consistent with the prior literature (e.g., Stickney and McGee, 1997; Richardson and Lanis, 2005) and supports hypothesis 2 (H2). This finding supports the notion that due to tax-deductible interest cost and agency theory, firms with higher leverage have lower ETR. In accordance with hypothesis 3 (H3), the results show a negative and significant coefficient for OL $(\beta=-0.719$, sig $=0.003)$, demonstrating that higher FCF is positively associated with ETR $(\beta=0.188$, sig $=0.014)$. As discussed in connection with the hypothesis development, this can be due to information asymmetries such that the principals are obviously not able to monitor the agents in a way that would deter the accumulation of free cash flow. This may reduce agents' efforts to decrease ETR. 
Table 5. Estimation results of a fixed effect model for ETR using FOREIGN as a proxy for foreign operations

\begin{tabular}{lc}
\hline Independent variables & ETR \\
\hline SIZE & $0.026^{*}$ \\
LEVERAGE & $(0.072)$ \\
& $-0.014^{* *}$ \\
OL & $(0.044)$ \\
& $-0.719^{* * *}$ \\
FCF & $(0.003)$ \\
& $0.188^{* *}$ \\
ROA & $(0.014)$ \\
& $-0.008^{* * *}$ \\
FOREIGN & $(0.000)$ \\
& $-0.071^{* *}$ \\
MATURE & $(0.049)$ \\
& -0.012 \\
GROWTH & $(0.371)$ \\
& $0.022^{* *}$ \\
Constant & $(0.016)$ \\
& 0.094 \\
Observations & $(0.506)$ \\
Number of firms & 2,731 \\
Year dummies & 487 \\
Wald test indep. variables & YES \\
Wald test indep. variables_pvalue & 200.9 \\
Wald test years & 0.000 \\
Wald test years_pvalue & 3,427 \\
\hline
\end{tabular}

Notes: Table 5 provides panel regressions using the within-group estimators Driscoll and Kraay standard errors for fixed effects. Coefficients are followed by $p$-values in parentheses. The results for the test of the joint significance of explanatory variables and year dummies are reported (Wald test indep. variables and Wald test years, respectively). The independent variables are winsorized at the $1^{\text {st }}$ and $99^{\text {th }}$ percentile. The variables are as defined in Table $1 . *^{* *}$, $* *$, and * indicate the $1 \%, 5 \%$, and $10 \%$ significance levels, respectively.

In accordance with hypothesis $5(H 5)$, a negative and significant coefficient emerges for foreign operations $(\beta=$ -0.071 , sig $=0.049$ ). This finding indicates that multinational firms have opportunities for tax strategies, which results in lower ETR. In line with the findings of Rego (2003), it appears that more profitable firms engage in non-conforming tax avoidance. The results show a negative and significant association between ETR and ROA, supporting hypothesis 7 (H7). As expected in $H 6 a$, a positive relationship is detected between GROWTH and ETR $(\beta$ $=0.022$, sig $=0.016)$. Hence, growth firms may focus more on operations than on tax avoidance strategies. Since ETR includes accounting earnings as the denominator, the results can only be inferred with regard to non-confirming tax avoidance. Conforming tax avoidance that results in tax deduction and lower accounting earnings are not captured by the ETR used in the paper (see Hanlon \& Heitzman, 2010). However, the regression shows no significance for MATURE. Overall, except for MATURE, the analysis shows the expected relationships between ETR and firm characteristics.

The results for the analysis of GTR08 on ETR and its impact on firm-specific factors are presented in Table 6. Investigating the overall sample, TR08 is negative and significant $(\beta=-0.062$, sig $=0.034)$, which implies that the tax reform has a negative effect on ETR. It appears that the reduction in tax rates overcompensates the limitations of deductions of the tax base and supports the hypothesis eight (H8). Supporting the results above, LEVERAGE, OL, ROA and FOREIGN show a negative association with ETR, While FCF has a positive relationship with ETR in the pre-tax reform period. In contrast to my findings above, MATURE show a negative association. However, I do not find significant coefficients for SIZE and GROWTH before GTR08. I find evidence that the association between ETR and ROA, MATURE, and GROWTH is positively impacted after the tax reform $(\beta=0.002$, sig $=0.067 ; \beta=$ 0.053 , sig $=0.018$; and $\beta=0.031$, sig $=0.059$, respectively). To analyze the relationship between firm-specific factors and ETR, I estimate the sum of their coefficients and the interaction term (e.g., TR08+TR08*SIZE). The association with ETR remains negative for LEVERAGE, ROA, and FOREIGN in the pre- and post-GTR08 period. I find evidence that greater size $(\beta=-0.060$, sig $=0.032)$, higher leverage $(\beta=-0.062$, sig $=0.040)$, free cash flow $(\beta=$ -0.065 , sig $=0.031)$, ROA $(\beta=-0.061$, sig $=0.039)$, foreign companies $(\beta=-0.058$, sig $=0.013)$, and growth firms $(\beta$ 
$=-0.031$, sig $=0.092)$ are associated with lower ETR in the post-tax reform period. However, while OL is negatively associated with ETR in the pre-tax reform period $(\beta=-0.798$, sig $=0.008)$, the sum of TR08+TR08*OL is not significant. Furthermore, while FCF is positively related to ETR before GTR08, there is a negative relationship in the post-tax reform period. Overall, I conclude that GTR affected ETR and impacted the association of firm characteristics with ETR.

Furthermore, I analyze more and less levered firms in detail. Therefore, I first split the sample by the $75^{\text {th }}$ and $25^{\text {th }}$ percentile and investigate the subsamples separately. For more levered firms (LEVERAGE $>75$ th percentile), I find a positive coefficient for TR08*LEVERAGE $(\beta=0.019$, sig $=0.097)$. This implies that the reduction of interest expenses positively affected ETR, supporting the hypothesis nine (H9). For less levered firms, there is significant impact of GTR08 on the association between LEVERAGE and ETR. However, the results need to be interpreted with caution because the sample is significantly reduced. To robust these results, I include two dummy variables LEVERAGE_high and LEVERAGE_low. I find comparable results as for the subsamples. However, the findings show no support of the hypothesis ten (H10). On average, there is no significant impact of GTR08 on OL.

Table 6. Estimation results of a fixed effect model for ETR analyzing GTR08

\begin{tabular}{|c|c|c|c|c|}
\hline Independent variables & $\begin{array}{c}\text { overall sample } \\
\text { ETR }\end{array}$ & $\begin{array}{c}\text { LEVERAGE }>75 \text { th } \\
\text { percentile } \\
\text { ETR }\end{array}$ & $\begin{array}{c}\text { LEVERAGE }<25 \text { th } \\
\text { percentile } \\
\text { ETR }\end{array}$ & $\begin{array}{c}\text { overall sample } \\
\text { LEVERAGE_high, } \\
\text { LEVERAGE_low } \\
\text { ETR }\end{array}$ \\
\hline SIZE & $\begin{array}{c}0.018 \\
(0.192)\end{array}$ & $\begin{array}{c}0.031 \\
(0.431)\end{array}$ & $\begin{array}{l}-0.021 \\
(0.534)\end{array}$ & $\begin{array}{c}0.020 \\
(0.166)\end{array}$ \\
\hline LEVERAGE & $\begin{array}{c}-0.015^{* *} \\
(0.039)\end{array}$ & $\begin{array}{l}-0.027 \\
(0.142)\end{array}$ & $\begin{array}{c}-0.046^{* *} \\
(0.016)\end{array}$ & $\begin{array}{c}-0.017 * * \\
(0.034)\end{array}$ \\
\hline OL & $\begin{array}{c}-0.798 * * * \\
(0.008)\end{array}$ & $\begin{array}{c}0.824 * * * \\
(0.006)\end{array}$ & $\begin{array}{l}-0.326 \\
(0.424)\end{array}$ & $\begin{array}{c}-0.777 * * * \\
(0.010)\end{array}$ \\
\hline FCF & $\begin{array}{c}0.199 * * \\
(0.016)\end{array}$ & $\begin{array}{c}0.190^{* * *} \\
(0.005)\end{array}$ & $\begin{array}{c}0.303^{* * *} * \\
(0.001)\end{array}$ & $\begin{array}{c}0.198^{* *} \\
(0.017)\end{array}$ \\
\hline ROA & $\begin{array}{c}-0.009 * * * \\
(0.000)\end{array}$ & $\begin{array}{l}-0.008^{*} \\
(0.082)\end{array}$ & $\begin{array}{c}-0.009 * * * \\
(0.000)\end{array}$ & $\begin{array}{c}-0.009 * * * \\
(0.000)\end{array}$ \\
\hline FOREIGN & $\begin{array}{c}-0.073^{* *} \\
(0.024)\end{array}$ & $\begin{array}{l}-0.176 \\
(0.157)\end{array}$ & $\begin{array}{l}-0.128 \\
(0.129)\end{array}$ & $\begin{array}{c}-0.072 * * \\
(0.026)\end{array}$ \\
\hline MATURE & $\begin{array}{c}-0.047 * * * \\
(0.008)\end{array}$ & $\begin{array}{c}-0.146 * * * \\
(0.002)\end{array}$ & $\begin{array}{c}0.017 \\
(0.710)\end{array}$ & $\begin{array}{c}-0.048^{* *} \\
(0.010)\end{array}$ \\
\hline GROWTH & $\begin{array}{c}0.008 \\
(0.371)\end{array}$ & $\begin{array}{l}0.048 \\
(0.144)\end{array}$ & $\begin{array}{l}-0.009 \\
(0.549)\end{array}$ & $\begin{array}{c}0.009 \\
(0.372)\end{array}$ \\
\hline TR08 & $\begin{array}{c}-0.062^{* *} \\
(0.034)\end{array}$ & $\begin{array}{l}-0.004 \\
(0.963)\end{array}$ & $\begin{array}{l}-0.049 \\
(0.538)\end{array}$ & $\begin{array}{l}-0.039 \\
(0.148)\end{array}$ \\
\hline TR08*SIZE & $\begin{array}{c}0.003 \\
(0.170)\end{array}$ & $\begin{array}{l}-0.001 \\
(0.898)\end{array}$ & $\begin{array}{l}-0.009 \\
(0.315)\end{array}$ & $\begin{array}{l}-0.000 \\
(0.985)\end{array}$ \\
\hline TR08*LEVERAGE & $\begin{array}{l}-0.000 \\
(0.998)\end{array}$ & $\begin{array}{l}0.019^{*} \\
(0.097)\end{array}$ & $\begin{array}{l}-0.003 \\
(0.808)\end{array}$ & \\
\hline TR08*LEVERAGE_low & & & & $\begin{array}{l}-0.002 \\
(0.904)\end{array}$ \\
\hline TR08*LEVERAGE_high & & & & $\begin{array}{c}0.031^{* *} \\
(0.028)\end{array}$ \\
\hline TR08*OL & $\begin{array}{c}0.133 \\
(0.345)\end{array}$ & $\begin{array}{l}-0.917 * \\
(0.052)\end{array}$ & $\begin{array}{l}-0.013 \\
(0.955)\end{array}$ & $\begin{array}{c}0.120 \\
(0.388)\end{array}$ \\
\hline TR08*FCF & $\begin{array}{l}-0.003 \\
(0.306)\end{array}$ & $\begin{array}{c}0.013^{* * * *} \\
(0.000)\end{array}$ & $\begin{array}{l}-0.011 \\
(0.182)\end{array}$ & $\begin{array}{l}-0.003 \\
(0.316)\end{array}$ \\
\hline TR08*ROA & $\begin{array}{l}0.002^{*} \\
(0.067)\end{array}$ & $\begin{array}{c}0.002 \\
(0.358)\end{array}$ & $\begin{array}{l}0.001^{*} \\
(0.091)\end{array}$ & $\begin{array}{l}0.002^{*} \\
(0.069)\end{array}$ \\
\hline TR08*FOREIGN & $\begin{array}{c}0.005 \\
(0.764)\end{array}$ & $\begin{array}{c}0.066 \\
(0.247)\end{array}$ & $\begin{array}{l}0.216^{* *} \\
(0.027)\end{array}$ & $\begin{array}{c}0.007 \\
(0.670)\end{array}$ \\
\hline TR08*MATURE & $\begin{array}{l}0.053^{* *} \\
(0.018)\end{array}$ & $\begin{array}{c}0.132 * * \\
(0.026)\end{array}$ & $\begin{array}{l}-0.005 \\
(0.866)\end{array}$ & $\begin{array}{l}0.054^{* *} \\
(0.018)\end{array}$ \\
\hline TR08*GROWTH & $\begin{array}{l}0.031^{*} \\
(0.059)\end{array}$ & $\begin{array}{c}0.025 \\
(0.328)\end{array}$ & $\begin{array}{l}0.107^{* *} \\
(0.015)\end{array}$ & $\begin{array}{l}0.030^{*} \\
(0.073)\end{array}$ \\
\hline Constant & $\begin{array}{c}0.198 \\
(0.217)\end{array}$ & $\begin{array}{c}0.086 \\
(0.844)\end{array}$ & $\begin{array}{c}0.632 \\
(0.107)\end{array}$ & $\begin{array}{c}0.182 \\
(0.252)\end{array}$ \\
\hline Observations & 2,731 & 682 & 682 & 2,731 \\
\hline Number of firms & 487 & 206 & 207 & 487 \\
\hline Year dummies & YES & YES & YES & YES \\
\hline
\end{tabular}


Table 6. Estimation results of a fixed effect model for ETR analyzing GTR08 (Continued)

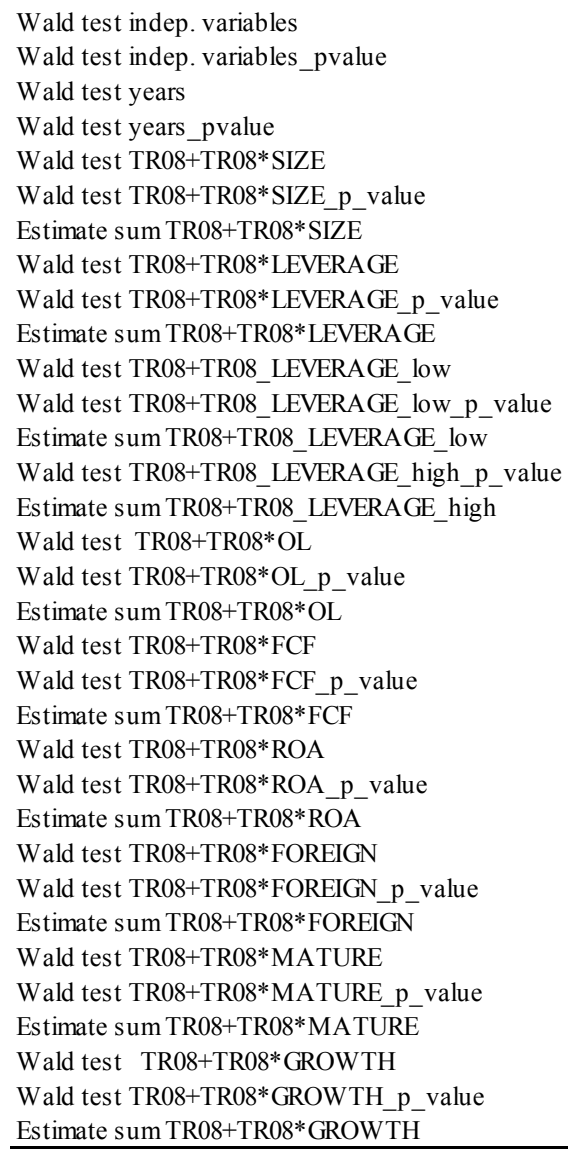

$\begin{array}{ccc}290 & 13 & 12 \\ 0.000 & 0.003 & 0.004 \\ 4,113 & 328 & 4,201 \\ 0.000 & 0.000 & 0.000 \\ 7.786 & 0.00402 & 0.759 \\ 0.032 & 0.952 & 0.417 \\ -0.060 & -0.005 & -0.058 \\ 6.796 & 0.023 & 0.409 \\ 0.040 & 0.884 & 0.546 \\ -0.062 & 0.015 & -0.052\end{array}$

0.126

$-0.040$

0.758

$-0.008$

0.301

0.603

0.082

3.073

0.130

$-0.042$

2.480

0.166

$-0.037$

2.579

0.159

$-0.032$

0.984

0.359

0.015

0.176

0.689

$-0.009$

Notes: Table 6 provides the results for the panel regression using the Driscoll and Kraay within-group estimator for standard errors analyzing the impact of GTR08. The results for the test of the joint significance of explanatory variables and year dummies are reported (Wald test indep. variables and Wald test years, respectively). We test whether the sum of the dummy variable TR08 and the individual interaction term equals 0 (e.g. Wald test TR08+TR08*SIZE) and estimate their sum (e.g., Estimate sum TR08+TR08*SIZE). For the estimated sum of coefficients, the $p$-value is the same as when using the Wald test. The independent variables are winsorized at the $1^{\text {st }}$ and $99^{\text {th }}$ percentile. The variables are as defined in Table $1 .{ }^{* * *},{ }^{* *}$, and $*$ indicate the $1 \%, 5 \%$, and $10 \%$ significance levels, respectively.

\subsection{Robustness Checks}

To verify the robustness of my results and to analyze foreign operations in detail, the dummy variable (FOREIGNDUM) is included for firms that started to report foreign sales in the period under review. FOREIGNDUM equals 1 if a firm reports foreign operations and 0 otherwise. The dummy variable captures the effect on ETR if a firm starts to report foreign sales during the period in question. For firms that do not change their reporting about foreign sales, FOREIGNDUM is 0 or 1 over the whole period. This represents a time-invariant effect that is captured by $\beta \mathrm{s}$. Therefore, the effect of foreign operations on ETR cannot be extracted. However, for firms that change their reporting this effect is captured by the coefficient of FOREIGNDUM. A negative coefficient of FOREIGNDUM indicates that multinational firms have lower ETR. This would support the hypothesis 5 (H5). The regression for ETR using FOREIGNDUM is as follows:

$$
\begin{aligned}
\text { ETR R }_{i t}= & \beta_{0}+\beta_{1} \text { SIZE }_{i t}+\beta_{2} \text { LEVERAGE }_{i t}+\beta_{3} O L_{i t}+\beta_{4} \text { FCF }_{i t}+\beta_{5} \text { ROA }_{i t}+ \\
& \beta_{6} \text { FOREIGNDUM }_{i t}+\beta_{7} \text { GROWTH }_{i t}+\beta_{8} \text { MATURE }_{i t}+\eta_{i}+d_{t}+\varepsilon_{i t}
\end{aligned}
$$

Table 7 presents the regression results using FOREIGNDUM to capture the effects on ETR if the firm starts to report foreign sales. Overall, the regression supports the findings reported above. There is a positive (negative) and significant coefficient for SIZE, ROA and GROWTH (LEVERAGE, OL, and FCF) and a negative and significant relationship between ETR and FOREIGNDUM, supporting the above results as well as $H 5$. 
The dummy variable FOREIGNDUM is interacted with the explanatory variables and a detailed analysis performed of whether multinational firms differ from companies that do not change their reporting of foreign sales. For instance, the effect of firm size on ETR for multinational firms that start to report foreign sales is captured by the sum of coefficients $\left(\beta_{1}+\beta_{8}\right)$. If these multinational companies have lower ETR than other firms, $\beta_{8}$ should be negative. To compare the coefficients of two groups of firms, we examine whether the sum of coefficient is significantly different from zero (e.g. $\mathrm{H}_{0}=\beta_{1}+\beta_{8}=0$ ). We also estimate the sum of coefficients of FOREIGNDUM and the individual interaction term. Its $p$-value is the same as that which results from the Wald test. The regression equation that includes the interaction terms is as follows:

$$
\begin{aligned}
\text { ETR }_{i t}= & \beta_{0}+\beta_{1} \text { SIZE }_{i t}+\beta_{2} \text { LEVERAGE }_{i t}+\beta_{3} \text { OL }_{i t}+\beta_{4} \text { FCF }_{i t}+\beta_{5} \text { ROA }_{i t}+\beta_{6} \text { FOREIGNDUM }_{i t} \\
& +\beta_{7} \text { GROWTH }_{i t}+\beta_{8} \text { MATURE }_{i t}+\beta_{9} \text { FOREIGNDUM }_{i t} * \text { SIZE }_{i t}+\beta_{10} \text { FOREIGNDUM }_{i t} * \text { LEVERAGE }_{i t} \\
& +\beta_{11} \text { FOREIGNDUM }_{i t} * \text { OL L }_{i t}+\beta_{12} \text { FOREIGNDUM }_{i t} * \text { FCF }_{i t}+\beta_{13} \text { FOREIGNDUM }_{i t} * \text { ROA }_{i t}+ \\
& \beta_{14} \text { FOREIGNDUM }_{i t} * \text { GROWTH }_{i t}+\beta_{15} \text { FOREIGNDUM }_{i t} * \text { MATURE }_{i t}+\eta_{i}+d_{t}+\varepsilon_{i t}
\end{aligned}
$$

The regression shows comparable results for continuous variables and for FOREIGNDUM, as described above. For firms that do not change their reporting of foreign sales, LEVERAGE, OL, and mature firms show negative and significant coefficients. Supporting the findings above, FOREIGNDUM is negative and significant. Hence, it appears that firms that start to report foreign returns are associated with lower ETR. This supports the notion that multinational firms have more options to exploit tax differences. Unlike firms that do not change their reporting, the estimated sum of FOREIGNDUM+FOREIGNDUM*SIZE is negative $(-0.187)$ and significant $($ sig. $=0.007)$. This indicates that larger multinational firms have more tax strategies at their disposal, resulting in lower ETR. Leverage and profitability remain significant $(\mathrm{sig}=0.007)$ and negative $(-0.190$ and -0.200 , respectively). The estimated sum of coefficients of growth and mature firms is negative ( -0.229 and -0.167 , respectively) and significant ( $\operatorname{sig}=0.007$ and sig $=0.014$ ). This indicates that both groups of firms have lower ETR when they operate in different regions.

\begin{tabular}{|c|c|c|}
\hline Independent variables & ETR & ETR \\
\hline SIZE & $\begin{array}{l}0.023 * \\
(0.081)\end{array}$ & $\begin{array}{c}0.013 \\
(0.368)\end{array}$ \\
\hline LEVERAGE & $\begin{array}{c}-0.014 * * \\
(0.044)\end{array}$ & $\begin{array}{c}-0.018 * * * \\
(0.005)\end{array}$ \\
\hline $\mathrm{OL}$ & $\begin{array}{c}-0.708 * * * \\
(0.003)\end{array}$ & $\begin{array}{c}-1.004 * * * \\
(0.003)\end{array}$ \\
\hline FCF & $\begin{array}{l}0.189 * * \\
(0.015)\end{array}$ & $\begin{array}{l}0.194 * * \\
(0.022)\end{array}$ \\
\hline FOREIGNDUM & $\begin{array}{c}-0.008 * * * \\
(0.000)\end{array}$ & $\begin{array}{c}-0.008 * * * \\
(0.000)\end{array}$ \\
\hline ROA & $\begin{array}{l}-0.043 * \\
(0.079)\end{array}$ & $\begin{array}{c}-0.199 * * * \\
(0.007)\end{array}$ \\
\hline MATURE & $\begin{array}{l}-0.012 \\
(0.392)\end{array}$ & $\begin{array}{c}-0.034 * * \\
(0.033)\end{array}$ \\
\hline GROWTH & $\begin{array}{l}0.023 * * \\
(0.017)\end{array}$ & $\begin{array}{c}0.044 * * * \\
(0.001)\end{array}$ \\
\hline FOREIGNDUM*SIZE & & $\begin{array}{l}0.012 * * \\
(0.014)\end{array}$ \\
\hline FOREIGNDUM*LEVERAGE & & $\begin{array}{c}0.009 \\
(0.230)\end{array}$ \\
\hline FOREIGNDUM*OL & & $\begin{array}{l}0.813 * * \\
(0.027)\end{array}$ \\
\hline FOREIGNDUM $*$ FCF & & $\begin{array}{l}-0.002 \\
(0.526)\end{array}$ \\
\hline FOREIGNDUM*ROA & & $\begin{array}{c}-0.001 * * * \\
(0.010)\end{array}$ \\
\hline FOREIGNDUM*MATURE & & $\begin{array}{c}0.033 * * \\
(0.031)\end{array}$ \\
\hline FOREIGNDUM*GROWTH & & $\begin{array}{c}-0.030^{* *} \\
(0.039)\end{array}$ \\
\hline Constant & $\begin{array}{c}0.126 \\
(0.361)\end{array}$ & $\begin{array}{c}0.258 \\
(0.136)\end{array}$ \\
\hline Observations & 2,731 & 2,731 \\
\hline Number of firms & 487 & 487 \\
\hline Year dummies & YES & YES \\
\hline
\end{tabular}
However, contrary to other firms, the estimated sum of FOREIGNDUM+FOREIGNDUM*OL is positive (0.614), while FOREIGNDUM+FOREIGNDUM*FCF is negative (-0.201).

Table 7. Estimation results of a fixed effect model for ETR using FOREIGNDUM as a proxy for foreign operations 
Table 7. Estimation results of a fixed effect model for ETR using FOREIGNDUM as a proxy for foreign operations (Continued)

\begin{tabular}{lcc} 
Wald test indep. variables & 230 & 147 \\
Wald test indep. variables_pvalue & 0.000 & 0.000 \\
Wald test years & 4,252 & 3,928 \\
Wald test years_pvalue & 0.000 & 0.000 \\
Wald test FOREIGNDUM+FOREIGNDUM*SIZE & 16.13 \\
Wald test FOREIGNDUM+FOREIGNDUM*SIZE_p_value & 0.007 \\
Estimate sumFOREIGNDUM+FOREIGNDUM*SIZE & -0.187 \\
Wald test FOREIGNDUM+FOREIGNDUM*LEVERAGE & 16.36 \\
Wald test FOREIGNDUM+FOREIGNDUM*LEVERAGE_p_value & 0.007 \\
Estimate sumFOREIGNDUM+FOREIGNDUM*LEVERAGE & -0.190 \\
Wald test FOREIGNDUM+FOREIGNDUM*OL & 4.687 \\
Wald test FOREIGNDUM+FOREIGNDUM*OL_p_value & 0.074 \\
Estimate sumFOREIGNDUM+FOREIGNDUM*OL & 0.614 \\
Wald test FOREIGNDUM+FOREIGNDUM*FCF & 15.87 \\
Wald test FOREIGNDUM+FOREIGNDUM*FCF_p_value & 0.007 \\
Estimate sumFOREIGNDUM+FOREIGNDUM*FCF & -0.201 \\
Wald test FOREIGNDUM+FOREIGNDUM*ROA & 15.94 \\
Wald test FOREIGNDUM+FOREIGNDUM*ROA_p_value & 0.007 \\
Estimate sumFOREIGNDUM+FOREIGNDUM*ROA & -0.200 \\
Wald test FOREIGNDUM+FOREIGNDUM*MATURE & 11.69 \\
Wald test FOREIGNDUM+MATURE_p_value & 0.014 \\
Estimate sumFOREIGNDUM+FOREIGNDUM*MATURE & -0.167 \\
Wald test FOREIGNDUM+FOREIGNDUM*GROWTH & 16.70 \\
Wald test FOREIGNDUM+FOREIGNDUM*GROWTH_p_value & 0.006 \\
Estimate sumFOREIGNDUM+FOREIGNDUM*GROWTH & -0.229 \\
\hline &
\end{tabular}

Notes: Table 7 provides the results for the panel regression using the Driscoll and Kraay within-group estimator for standard errors. The results for the test of the joint significance of explanatory variables and year dummies are reported (Wald test indep. variables and Wald test years, respectively). We test whether the sum of the dummy variable and the individual interaction term equals 0 (e.g. Wald test FOREIGNDUM+FOREIGNDUM*SIZE) and estimate their sum (e.g., Estimate sum FOREIGNDUM+FOREIGNDUM*SIZE). For the estimated sum of coefficients, the $p$-value is the same as when using the Wald test. The independent variables are winsorized at the $1^{\text {st }}$ and $99^{\text {th }}$ percentile. The variables are as defined in Table $1 .{ }^{* * *},{ }^{* *}$, and $*$ indicate the $1 \%, 5 \%$, and $10 \%$ significance levels, respectively.

Dhaliwal et al. (2004) use foreign operations scaled by pre-tax income to analyze the relationship between tax expenses and earnings management. Using their measure for the international structure of companies, the results do not change (not reported here).

Overall, it appears that larger companies and growth firms have higher ETR. Higher leverage and operating lease expenses lead to lower ETR. More profitable firms tend to avoid taxes since the relationship between ETR and ROA is negative. Furthermore, multinational firms appear to have more possibilities to reduce their tax burden.

\section{Conclusions}

This paper uses longitudinal data to examine whether firm-specific characteristics of German listed firms are associated with ETR spanning the Germany's tax reform of 2008. The results show that larger companies have higher ETR, supporting the political cost theory. As expected, higher leverage reduces ETR. The analysis shows that firms' leverage and operating lease expenses are associated with lower ETR. Moreover, FCF is positively related to ETR. This may be due to the information asymmetries that reduce managers' efforts to reduce their company's tax burden. The results indicate that more profitable firms appear to engage in non-confirming tax avoidance that results in a negative association between ROA and ETR. Furthermore, growth firms tend to have higher ETR. Hence, it is possible that growth firms focus more on ordinary activities than on strategies to reduce their tax burden. Since these firms are highly valued by the capital market, they may engage less in tax strategies. However, no significant 
relationship is found for mature firms. Analyzing the proportion of foreign sales to total sales, multinational firms appear to have lower ETR. Firms that started to report foreign sales during the period under review are also associated with lower ETR. This supports the notion that multinational companies have more possibilities to exploit tax differences that result in lower ETR.

Investigating the effect of GTR08 on ETR and its impact on the association of firm-specific factors with ETR, I find evidence that the tax reform negatively affected ETR. Furthermore, GTR08 affected the relationship between firm characteristics and ETR leaving the direction of leverage, ROA, and foreign firms unchanged in the post-tax reform period. As expected, the association between LEVERAGE and ETR is positively affected by GTR08 for more levered firms resulting from limitations of interest deductions from the tax base.

The results of the study should be of interest to various groups such as regulatory authorities, who deal with profit shifting and broadness of tax bases, tax researchers, who analyze factors of ETR and impact of tax reforms as well as investors, who use tax-related information for their decisions. The findings of this study are subject to the following limitations. Tax loss carry-forwards induce zero or low tax payments but do not influence the accounting measure of the denominator. Thus they should have an influence on ETR. Other factors such as the extent of tax fees, executives' effects, ownership structure, or corporate reorganizations resulting in a merger or acquisition that may impact on ETR. Adding unlisted companies to the sample would make it easier to assess the interplay between the lawmakers' aim of neutral taxation and decisions about legal form. Future research could incorporate these issues, too.

\section{References}

Amstrong, C.S., Blouin, J. L., \& Larcker, D. F. (2012). The incentives for tax planning. Journal of Accounting and Economics, 53, 391-411. http://dx.doi.org/10.1016/j.jacceco.2011.04.001

Bundesrat. (2007). Unternehmensteuerreformgesetz 2008. Endfassung: Drucksache 384/07.

Chen, S, Chen, X., Cheng, Q., \& Shevlin, T. (2010). Are family firms more tax aggressive than non-family firms? Journal of Financial Economics, 95, 41-61. http://dx.doi.org/10.1016/j.jfineco.2009.02.003

Demple, U. (2006). Charakterisierung, Analyse und Beeinflussung der Konzernsteuerquote. Wiesbaden: Deutscher Universitäts-Verlag.

Dhaliwal, D., Gleason, C., \& Mills, L. (2004). Last-chance earnings management: using the tax expense to meet analysts' forecasts. Contemporary Accounting Research, 21, 431-459. http://dx.doi.org/10.1506/tfvv-uyt1-nnyt-1yfh

Dickinson, V. (2011). Cash Flow Patterns as a Proxy for Firm Life Cycle. The Accounting Review, 86, 1969-1994. http://dx.doi.org/10.2308/accr-10130

Driscoll, J. C., \& Kraay, A. C. (1998). Consistent Covariance Matrix Estimation with Spatially Dependent Panel Data. Review of Economics and Statistics, 80, 549-560. http://dx.doi.org/10.1162/003465398557825

Fama, E. F., \& French, K. R. (2007). The Anatomy of Value and Growth Stock Returns. Retrieved May 20, 2013, from http://papers.ssrn.com/sol3/papers.cfm?abstract_id=806664

Frank, M. M., Lynch, L. J., \& Rego, S. O. (2009). Tax reporting aggressiveness and its relation to aggressive financial reporting. The Accounting Review, 84, 467-496. http://dx.doi.org/10.2308/accr.2009.84.2.467

Graham, J. R. (2003). Taxes and Corporate Finance: A review. Review of Financial Studies, 16, 1075-1129. http://dx.doi.org/10.1093/rfs/hhg033

Grullon, G., Michaely, R., \& Swaminathan, B. (2002). Are Dividend Changes a Sign of Firm Maturity? The Journal of Business, 75, 387-424. http://dx.doi.org/10.1086/339889

Gupta, S., \& Newberry, K. (1997). Determinants of the Variability on Corporate Effective Tax Rates: Evidence from Longitudinal Data. Journal of Accounting and Public Policy, 16, 1-34. http://dx.doi.org/10.1016/s0278-4254(96)00055-5

Hanlon, M., \& Heitzman, S. (2010). A review of tax research. Journal of Accounting and Economics, 50, 127-178. http://dx.doi.org/10.1016/j.jacceco.2010.09.002

Herzig, N., \& Dempfle, U. (2002). Konzernsteuerquote, betriebliche Steuerpolitik und Steuerwettbewerb. Der Betrieb, 1, 1-8.

Jensen, M. C. (1986). Agency Costs of Free Cash Flow, Corporate Finance, and Takeovers. American Economic Review, 76, 323-329. http://dx.doi.org/10.1017/cbo9780511609435.005 
Jensen, M. C., \& Meckling, W. H. (1976). Theory of the Firm: Managerial Behaviour, Agency Costs and Ownership Structure. Journal of Financial Economics, 3, 305-360. http://dx.doi.org/10.1016/0304-405x(76)90026-x

Kessler, W., \& Eicke, R. (2007). Germany's Corporate Tax Reform - The Road Not Taken. Tax Notes International, 46, 1135-1137.

Liu, X., \& Cao, S. (2007). Determinants of Corporate Effective Tax Rates - Evidence from Listed Firms in China. The Chinese Economy, 40, 49-67. http://dx.doi.org/10.2753/ces1097-1475400603

Mahenthiran, S., \& Kasipillai, J. (2011). Influence of Ownership Structure, Corporate Governance, and Culture on Tax Policy: Evidence from Malaysia. Retrieved May 20, 2013, from http://ssrn.com/abstract=1752526

Mammen, A. (2011). Die Konzernsteuerquote als Lenkungsinstrument im Rahmen des Risikomanagementsystems börsennotierter Muttergesellschaften. Wiesbaden: Gabler Verlag.

Manzon, G. B., \& Plesko, G. A. (2002). The Relation Between Financial and Tax Reporting Measures of Income. Tax Law Review, 55, 175-213. http://dx.doi.org/10.2139/ssrn.264112

Markle, K. S., \& Shackelford, D. A. (2010). Cross-Country Comparisons of Corporate Income Taxes. NBER Working Paper No. 16839.

Mills, L., Erickson, M. M., \& Maydew, E. L. (1998). Investments in Tax Planning. Journal of the American Taxation Association, 20, 1-20. http://dx.doi.org/10.2308/jata.2000.22.s-1.51

Mohanram, P. S. (2005). Separating Winners from Losers among Low Book-to-Market Stocks using Financial Statement Analysis. Review of Accounting Studies, 10, 133-170. http://dx.doi.org/10.1007/s11142-005-1526-4

Nelson, M., Elliott, J., \& Tarpley, R. (2002). Evidence from auditors about managers' and auditors' earnings-management decisions. The Accounting Review, 11(Supplement), 175-202. http://dx.doi.org/10.2308/accr.2002.77.s-1.175

OECD. (2013a). Report on Base Erosion and Profit Shifting (BEPS).

OECD. (2013b). Action Plan on Base Erosion and Profit Shifting (BEPS).

Omer, T. C., Molloy, K. H., \& Ziebart, D. A. (1991). Measurement of Effective Corporate Tax Rates Using Financial Statements Information. The Journal of the American Taxation Association, 13, 57-72.

Porcano, T. M. (1983). Corporate tax rates: Progressive, proportional, or regressive. Journal of the American Taxation Association, 7, 17-31.

Rajan, R. G., \& Zingales, L. (1995). What Do We Know About Capital Structure? Some Evidence from International Data. Journal of Finance, 50, 1421-60. http://dx.doi.org/10.1111/j.1540-6261.1995.tb05184.x

Rajan, R. G., \& Zingales, L. (2003). The great reversals: the politics of financial development in the twentieth century. Journal of Financial Economics, 69, 5-50. http://dx.doi.org/10.1016/s0304-405x(03)00125-9

Rego, S. O. (2003). Tax-avoidance Activities of U.S. Multinational Corporations. Contemporary Accounting Research, 20, 805-833. http://dx.doi.org/10.1506/vann-b7ub-gmfa-9e6w

Richardson, G., \& Lanis, R. (2007). Determinants of the Variability in Corporate Effective Tax Rates and Tax Reform: Evidence from Australia. Journal of Accounting and Public Policy, 26, 689-704. http://dx.doi.org/10.1016/j.jaccpubpol.2007.10.003

Schmidt, A. (2006). The persistence, forecasting, and valuation implications of the tax change components of earnings. The Accounting Review, 81, 589-616. http://dx.doi.org/10.2308/accr.2006.81.3.589

Siegfried, J. (1972). The Relationship Between Economic Structure and the Effect of Political Influence: Empirical Evidence from the Federal Corporation Income Tax Program. Dissertation, University of Wisconsin.

Slemrod, J., \& Blumenthal, M. (1993). The Income Tax Compliance Costs of Big Business. Washington D.C.: The Tax Foundation.

Stickney, C. P., \& McGee, V. E. (1982). Effective Corporate Tax Rates: The Effect of Size, Capital Intensity, Leverage and Other Factors. Journal of Accounting and Public Policy, 1, 125-152. http://dx.doi.org/10.1016/s0278-4254(82)80004-5

Sureth, C., Halberstadt, A., \& Bischoff, D. (2009). Internationale Besteuerung - Der Einfluss von Internationalisierung, Vermögens- und Kapitalstruktur auf die Konzernsteuerquote im Branchenvergleich - Eine empirische Analyse. Steuer und Wirtschaft, 86, 50-62. 
Wahab, N. S. A., \& Holland, K. (2012). Tax Planning, Corporate Governance and Equity Value. British Accounting Review, 44, 111-124. http://dx.doi.org/10.1016/j.bar.2012.03.005

Watts, R. L., \& Zimmerman, J. L. (1990). Positive Accounting Theory: A Ten Year Perspective. The Accounting Review, 65, 131-156.

Wilkie, P. J. (1988). Corporate Average Effective Tax Rates and Inferences about Relative Tax Preferences. Journal of the American Taxation Association, 10, 75-88.

Wilkie, P. J., \& Limberg, S. T. (1990). The Relationship Between Firm Size and Effective Tax Rate: A Reconciliation of Zimmerman [1983] and Porcano [1986]. Journal of the American Taxation Association, 11, 76-91.

Zimmerman, J. L. (1983). Taxes and Firm Size. Journal of Accounting and Economics, 5, $119-149$. http://dx.doi.org/10.1016/0165-4101(83)90008-3

\section{Notes}

Note 1. Further details are discussed in section $3 b$ ).

Note 2. Registered office or headquarters in Germany. 